\title{
Investigation of Gene Polymorphisms of Vaspin, Visfatin and Chemerin in Diabetic Obese and Non-Diabetic Obese Patients
}

\author{
Diyabetik Obez ve Diyabetik Olmayan Obez Hastalarda Vaspin, Visfatin ve Kemerin Gen \\ Polimorfizimlerinin İncelenmesi
}

Fikret Kaan ORAN ${ }^{1}$ (D), Arezoo GHEYBI ${ }^{1}$ (D), Faruk CELIK $^{1}$ (D), Sermin DURAK ${ }^{1}$ (D), Zeliha DOGAN²(iD), Saadet Busra AKSOYER SEZGIN $^{3}$ (D), Cem BASARAN ${ }^{4}$ (D), Osman FAZLIOGULLARI ${ }^{5}$ (D), Nur Gokce CETINER ${ }^{1}$ (i), Sakir Umit ZEYBEK $^{1}$ (iD)

\begin{abstract}
Diabetes mellitus and obesity are very similar in terms of pathogenesis and pathophysiology. Most obese patients have adipose tissue dysfunction caused by genetic and environmental factors. Adipose tissue is the source of adipokines secreted from adipocytes. Vaspin (visceral adşpose tissue-derived serine protease inhibitor), Visfatin (pre-B cell enhancing factor) and Chemerin are adipokines discovered in recent years. The study consists of 43 non-diabetic obese and 51 diabetic obese individuals. The PCRRFLP method and agarose gel electrophoresis techniques were used to detect gene polymorphisms of Chemerin rs17173608, Vaspin rs2236242 and Visfatin rs2110385 from DNA samples. In our study, when diabetic obese and non-diabetic obese patient groups were examined in terms of Vaspin gene polymorphism, statistically significant results were obtained $(22 \% \rightarrow 7 \%$, $\mathrm{p}=0.048$, respectively). The distribution of Chemerin or Visfatin gene variants were not different in study groups $(\mathrm{p}>0.05)$. Our results indicate that Chemerin rs17173608 and Visfatin rs2110385 gene polymorphisms were not risk factors for development of diabetes in obese individuals, however, Vaspin rs2236242 gene
\end{abstract}

Sermin DURAK (两)

Istanbul University, Aziz Sancar Institute of Experimental Medicine, Department of Molecular Medicine, Vakif Gureba Cad., Sehremini-Fatih 34093 Istanbul, Turkey.

e-mail: sermingad@gmail.com

${ }^{1}$ Department of Molecular Medicine, Aziz Sancar Institute of Experimental Medicine, Istanbul University, Istanbul, Turkey.

${ }^{2}$ Altınbaş University, Vocational School of Health Services, Istanbul, Turkey.

${ }^{3}$ Biruni University, Vocational School, Istanbul, Turkey.

${ }^{4}$ Biruni University, Faculty of Medicine, Department of Medical Biochemistry,Istanbul,Turkey.

${ }^{5}$ Altınbaş University, Vocational School of Health Services, Istanbul, Turkey. polymorphism may be a contributory risk of development of diabetes in obese individuals.

Keywords: Diabetes, Obesity, Vaspin, Chemerin, Visfatin, Polymorphism

\section{Öz}

Diabetes mellitus (DM) ve obezite, patogenez ve patofizyoloji açısından çok benzerdir. Obezite hastalarının çoğunda, genetik ve çevresel faktörlerin yol açtığı adipoz doku fonksiyon bozukluğu bulunur. Adipoz doku, adipositlerden salgılanan mediyatörlerin (adipokinler) kaynağı olup Vaspin (visceral adipose tissue-derived serine protease inhibitor), Visfatin (pre-B cell enhancing faktör) ve Kemerin son yıllarda keşfedilen adipokinlerdir. Çalışmamıza 43 Diyabetik obez ve 51 Diyabetik olmayan obez hastalığ tanıs1 konulmuş toplam 95 hasta dahil edilmiştir. Hasta grubunun 10ml'lik kan örnekleri EDTA'lı tüplere toplanmıştır. DNA örneklerinden Kemerin rs17173608, Vaspin rs2236242 ve Visfatin rs2110385 polimorfizmlerini saptamak için PCR-RFLP method ve agaroz jel elektroforezi teknikleri kullanılmıştır. Çalışma grubumuz Vaspin gen polimorfizimi açısından incelendiğinde istatistiksel olarak anlamlı sonuçlar tespit edilmiş olup (sırasıyla $\% 22 \rightarrow \% 7, p=0.048$ ) Kemerin ve Visfatin gen varyantlarının dağılımı açısından istatistiksel olarak anlamlı bulunamamışıtr ( $p>0.05$ ). Sonuç olarak Kemerin rs 17173608 ve Visfatin rs 2110385 gen polimorfizmlerinin obez bireylerde diyabet gelişimi için risk faktörü olmadığını, ancak Vaspin rs2236242 gen polimorfizminin obez bireylerde diyabet gelişimi açısından bir risk faktörü olabileceği gösterilmiştir.

Anahtar Kelimer: Diyabet, Obezite, Vaspin, Kemerin, Visfatin, Polimorfizm

\section{INTRODUCTION}

In recent years, the prevalence of obesity has been increasing rapidly around the world and poses a major global health problem. The incidence of obesity is increasing day by day in our country, as in other countries of the world. 
Worldwide obesity has increased tripled since 1975 and nearly $13 \%$ of the world's adult individuals $(11 \%$ of men and $15 \%$ of women) were obese in 2016 [1]. According to the preliminary study report of "Turkey Nutrition and Health Survey-2010" conducted by Turkey Ministry of Health, the prevalence of obesity in Turkey was found $20.5 \%$ in men, $41.0 \%$ in women and $30.3 \%$ in total [2]. Physical inactivity due to increasing sedentary life, genetic and environmental factors, insulin resistance and adipose tissue dysfunction are observed in most obese individuals [3]. There are many diseases associated with obesity such as Type 2 Diabetes Mellitus (T2DM), musculoskeletal disorders, cardiovascular diseases, metabolic syndrome, and some cancer [1]. Obesity, on the other hand, is one of the most important risk factors in T2DM etiology. T2DM is characterized inefficient insulin secretion from langerhans beta cells in pancreatic islets that known as insulin resistance [4]. The resulting decrease in glucose uptake, mainly due to the reduced effect of insulin in target tissues such as adipose tissue, skeletal muscle and liver cells [5].

Adipose tissue is an endocrine organ and is responsible for the secretion of cytokines called adipocytokines or adipokines. These cytokines play important roles in carbohydrate and fat metabolism in the regulation of the hunger and satiety cycle. Adipokines are effective in the development of insulin resistance associated with obesity and also play a role in a wide variety of physiological and pathological processes, including immunity and inflammation, by showing endocrine, paracrine, autocrine and juxtracrine effects [6]. Excess adipose tissue lead to secretion of adipocytes and the development of chronic inflammation in obese individuals. There is increased expression of adhesion molecules along with adipokineinduced chemokines stimulate macrophage secretion from adipose tissue. İnsulin resistance development because of local inflammation [7]. Various pro-inflammatory peptides secreted by macrophages of adipose tissue in obesity; Tumor necrosis factor $-\alpha(\mathrm{TNF}-\alpha)$ and interleukin 6 (IL6) are evaluated as adipokine production [8]. These proinflammatory adipokines contribute a lot to the "low-grade inflammatory state" of obese cases and cause cardiovascular complications and autoimmune inflammatory diseases. In adipose tissue, also anti-inflammatory factors such as interleukin 1-receptor antagonist (IL-1RA) and IL-10 are produced which are significantly increased in obese patients [9]. Data from studies on mice suggest that this endogenous antagonist exerts both central and peripheral effects, thus increasing adipogenesis and leptin resistance. Also, the ratio IL-1RA/IL-1 favors IL-1RA and is the best IL-1RA inducer in interferon (IFN) - $\beta$ WAT. In addition, it cannot modulate leptin or adiponectin in IFN- $\beta$ WAT [8]. New ones are joining the adipokine family recently, and the most known ones are leptin, adiponectin, resistin, TNF- $\alpha$, interleukin-6, apelin, acylation stimulating protein, plasminogen activator inhibitor factor- 1 and renin angiotensin system proteins. The adipokines discovered in recent years are Vaspin (visceral adipose tissue - derived serine protease inhibitor), Visfatin (pre-B cell enhancing factor), and Chemerin [10]. Vaspin is a serine protease inhibitor produced in visceral adipose tissue. It has been suggested that Vaspin induction by adipose tissue may create a compensatory mechanism in response to obesity and inflammatory complications of obesity. Vaspin levels were found to increase significantly in obese and insulin resistant mice [11]. Vaspin can be considered as a new link between obesity and associated metabolic disorders, such as glucose intolerance [12]. Visfatin is an insulinmimicking adipokine discovered in liver, skeletal muscle and bone marrow as a growth factor for B lymphocyte precursors. Circulating Visfatin level is closely associated with white adipocyte tissue accumulation. Visfatin mRNA levels increase during adipocyte differentiation and Visfatin synthesis is regulated by various factors such as glucocorticoids, TNF, IL-6 and growth hormone [13]. Chemerin, also called retinoic acid receptor responsive protein 2 (RARRES2), is a new adipokine and its biological functions are not yet clear. Chemerin is a protein secreted by adipocytes and plays an autocrine / paracrine role in the development and function of adipose tissue. Chemerin and its major receptor Chemokine-like receptor 1 (CMKLR1) are secreted in white adipose tissue and increase in obese people and rodents $[14,15]$.

The studies are needed to achieve success in the fight against obesity, adipose tissue and the adipokines produced by them must be well known. Moreover, we think that the impaired adipokine production observed in obesity contributes to diabetes pathogenesis. We believe that there are differences in polymorphism in the adipokine genes in the pathophysiology of these two diseases. Our aim was to determine the differences in gene variations of adipose tissue adipokines of Chemerin rs 17173608, Vaspin rs2236242 and Visfatin rs 2110385 in diabetic obese and non-diabetic obese patients. 


\section{MATERIAL AND METHODS}

\section{Participants}

In this study, two separate sample groups were employed. The participants in the study were selected from 43 non-diabetic obese patients and 51 diabetic obese patients followed by Medicana Bahçelievler Hospital Cardiovascular Surgery Clinic.

All participants in the study provided their written consent prior to the study. Body Mass Index (BMI $\left.=\mathrm{kg} / \mathrm{m}^{2}\right)$ measurements of the patients were selected according to the age-related obesity limit. The weight, height and body composition measurements of the groups that were included in the study were recorded. The biochemical parameters, such as Aspartate Aminotransferase (AST), Alanine Aminotransferase (ALT), Blood Urea Nitrogen (BUN), keratin, platelet (PLT), sedimentation, urea, White Blood Cell (WBC), HbA1c, Low Density Lipoprotein-Cholesterol (LDL-Cholesterol), High Density Lipoprotein-Cholesterol (HDL-Cholesterol), Very Low-Density Lipoprotein (VLDL) were examined.

\section{DNA isolation and PCR-RFLP}

The genomic DNA was obtained by using saltingout technique [16]. The polymorphic genotyping was determined by using polymerase chain reaction (PCR), restriction fragment length polymorphism (RFLP) and Agarose Gel Electrophoresis Techniques as previously reported $[17,18,19]$. The Chemerin, Vaspin and Visfatin gene polymorphisms were performed by using Alu1 endonuclease restriction enzyme.

\section{Statistical Analysis}

The SPSS 21.0 software was used for statistical analysis. The statistical significance was accepted as $p<0.05$. Evaluation of relative risk was determined by calculating confidence intervals (CI) and odds ratio (OR). Student's t-test was used to determine the difference in biochemical parameters as mean \pm standard deviation. The Chi-Square $\left(\chi^{2}\right)$ and Fisher's Exact test were used to compare of genotypes distributions data as percentage (\%) and determine their effects on biochemical activity.

\section{RESULTS}

The present study includes 43 non-diabetes obese and 51 diabetes obese patients, and the study groups have a similar distribution of $\operatorname{sex}(p>0.05)$. The clinical data of the study groups were shown in Table 1. The cases participating in the study were evaluated in terms of biochemical and somatic parameters, such as age, height, weight, BMI, HbA1c, LDL, HDL, and low VLDL. Among these, it was determined that age caused significant differences between diabetic and non-diabetic groups (Table 1).

Table 1. Clinical data of diabetic and non-diabetic obese patient groups

\begin{tabular}{|l|l|l|l|}
\hline Clinical par. & $\begin{array}{l}\text { Non-Diabetic obese } \\
(\mathrm{n}=43)\end{array}$ & Diabetic obese $(\mathrm{n}=51)$ & $p$ value \\
\hline Age & $64.74 \pm 5.97$ & $61.47 \pm 9.38$ & $0.013^{*}$ \\
\hline BMI & $31.60 \pm 3.32$ & $31.93 \pm 3.27$ & 0.687 \\
\hline LDL & $118 \pm 44.59$ & $120.85 \pm 36.31$ & 0.733 \\
\hline AST & $28.16 \pm 17.55$ & $31.67 \pm 17.19$ & 0.119 \\
\hline ALT & $27.21 \pm 14.98$ & $35.00 \pm 27.06$ & 0.133 \\
\hline BUN & $20.86 \pm 9.97$ & $20.14 \pm 10.55$ & 0.586 \\
\hline Creatinine & $1.67 \pm 4.7$ & $1.10 \pm 1.15$ & 0.969 \\
\hline PLT & $271.8 \pm 66.01$ & $272.08 \pm 61.95$ & 0.983 \\
\hline ESR & $36.60 \pm 22.24$ & $32.61 \pm 23.27$ & 0.270 \\
\hline Urea & $42.45 \pm 17.94$ & $43.11 \pm 20.82$ & 0.734 \\
\hline WBC & $8.13 \pm 2.37$ & $7.60 \pm 1.99$ & 0.247 \\
\hline Weight & $81.29 \pm 11.17$ & $85.23 \pm 12.54$ & 0.087 \\
\hline HDL & $39.92 \pm 9.44$ & $38.17 \pm 9.44$ & 0.490 \\
\hline VLDL & $48.88 \pm 45.37$ & $38.79 \pm 9.44$ & 0.642 \\
\hline & & & \\
\hline
\end{tabular}

The difference between the groups was analyzed with student's t-test and Chi square $(\times 2)$ test. The bold values $p<0.05$ indicate statistical significance (Mean \pm Standard Deviation).

The distribution of genotype of Chemerin, Vaspin and Visfatin polymorphisms in the study groups was shown in Table 2. In our study, which was conducted with diabetic and non-diabetic obese individuals, Vaspin TT genotype was found to be statistically significant between the two groups $(22 \% \rightarrow 7 \%, p=0.048$, respectively). However, no significant differences were detected between the groups in Chemerin and Visfatin gene polymorphism $(p>0.05)$ (Table 2). 
Table 2. Genotypic distribution of Chemerin, Vaspin and Visfatin polymorphisms in diabetic and non-diabetic obese patients

\begin{tabular}{|c|c|c|c|}
\hline Genotypes & $\begin{array}{l}\text { Non }- \text { Diabetic } \\
\text { obese }(n=43, \%)\end{array}$ & $\begin{array}{l}\text { Diabetic obese } \\
(\mathrm{n}=51, \%)\end{array}$ & $\mathrm{p}$ value \\
\hline \multicolumn{4}{|c|}{ Chemerin rs: 17173608} \\
\hline $\mathrm{TT}(\mathrm{w})$ & $21(49 \%)$ & $20(39 \%)$ & \multirow{3}{*}{0.46} \\
\hline TA & $17(39 \%)$ & $22(43 \%)$ & \\
\hline AA & $5(12 \%)$ & $9(18 \%)$ & \\
\hline \multicolumn{4}{|c|}{ Vaspin rs: 2236242} \\
\hline $\mathrm{GG}(\mathrm{w})$ & $19(44 \%)$ & $15(29 \%)$ & \multirow{3}{*}{$0.048^{*}$} \\
\hline GT & $21(49 \%)$ & $25(49 \%)$ & \\
\hline TT & $3(7 \%)$ & $11(22 \%)$ & \\
\hline \multicolumn{4}{|c|}{ Visfatin rs: 2110385} \\
\hline $\mathrm{TT}(\mathrm{w})$ & $12(28 \%)$ & $8(16 \%)$ & \multirow{3}{*}{0.096} \\
\hline TG & $18(42 \%)$ & $19(37 \%)$ & \\
\hline GG & $13(30 \%)$ & $24(47 \%)$ & \\
\hline
\end{tabular}

The differences between the groups were analyzed with the Chi-Square $\left(X^{2}\right)$ test for values with percentage (\%). The bold values $p<0.05$ indicate statistical significance.

Moreover, the clinical parameters and possible diabetes risk factors (age, AST, LDL and BMI) were also not associated with homozygote mutation genotype Chemerin $(p>0.05)$ (Table 3). However, when evaluated in terms of age in the study of homozygote mutation genotype in Vaspin and Visfatin were found significant $(p=0.032$, OR:1.065, CI:1.005-1.128; $p=0.42$, OR:1.061, CI: 1.002-1.124; respectively). Therefore, the homozygote mutant polymorphism in Vaspin and Visfatin accompanied by increased age might increase the diabetes risk factor in obese patients (Table 3). On the other hand, AST, LDL and BMI show no significant differences in Vaspin and Visfatin homozygote mutation genotypes $(p>0.05)$ (Table 3 ).

Table 3. The evaluation of Chemerin Vaspin and Visfatin homozygote polymorphism genotypes in terms of diabetic risk factors in diabetic obese and non-diabetic patient groups.

\begin{tabular}{|l|l|l|l|}
\hline Genotypes and risk factors & OR & $95 \%$ CI & $p$ value \\
\hline Chemerin (AA) & 0.520 & $0.143-1.889$ & 0.320 \\
\hline Age & 1.052 & $0.995-1.112$ & 0.07 \\
\hline BMI & 0.985 & $0.865-1.122$ & 0.820 \\
\hline LDL & 1.001 & $0.990-1.012$ & 0.892 \\
\hline AST & 0.986 & $0.961-1.01$ & 0.261 \\
\hline Vaspin (TT) & 0.234 & $0.058-0.951$ & 0.042 \\
\hline Age & 1.065 & $1.005-1.128$ & $\mathbf{0 . 0 3 2}$ \\
\hline BMI & 1.008 & $0.880-1.115$ & 0.910 \\
\hline LDL & 1.002 & $0.991-1.013$ & 0.753 \\
\hline AST & 0.989 & $0.964-1.014$ & 0.386 \\
\hline Visfatin (GG) & 0.411 & $0.160-1.005$ & 0.065 \\
\hline Age & 1.061 & $1.002-1.124$ & $\mathbf{0 . 0 4 2}$ \\
\hline BMI & 1.020 & $0.889-1.70$ & 0.782 \\
\hline LDL & 1.002 & $0.991-1.014$ & 0.664 \\
\hline AST & 0.990 & $0.965-1.055$ & 0.437 \\
\hline
\end{tabular}

The differences between the groups were analyzed with Chi-Square $\left(X^{2}\right)$. The bold values $p<0.05$ indicate statistical significance (Mean \pm Standard Deviation).

\section{DISCUSSION}

Diabetes mellitus and obesity are very similar in terms of pathogenesis and pathophysiology. Most obesity patients have adipose tissue dysfunction caused by genetic and environmental factors. Adipose tissue is the source of adipokines secreted from adipocytes. In recent years, Vaspin, Visfatin, Chemerin are ones of the important adipokines.

The differences in polymorphisms in adipokine genes are thought to cause the pathophysiology of T2DM and obesity [20]. In this study, Chemerin, Vaspin and Visfatin gene were determined and the obtained findings were compared with clinical parameters in diabetic obese and non-diabetic obese patients.

Nora klö et al. (2006) reported that the Vaspin gene expression was found statistically significant in T2DM $(\mathrm{p}<0.0001)$ [21]. In the present study, statistically significant results were obtained in Vaspin gene polymorphism between the diabetic obese and non-diabetic obese patient groups $(22 \% \rightarrow 7 \%, p=0.048$, respectively $)$. Previous studies suggested the Vaspin gene might be an important marker in development both obesity and impaired insulin resistance $[22,9]$. Moreover, the Vaspin gene could be considered of T2DM in obese individuals. Feng et al. conducted in the study, the T2DM with obese patients, it was reported that there was a statistically significant relationship between serum HbA1c level and Vaspin level. In the same study, it was reported that there was a significant relationship between BMI and age in the control group [23]. In addition, Francisca Lago et al. reported that the age and gender regulate Vaspin gene expression and also Vaspin serum levels are associated with biochemical parameters [6]. In our study, we found statistically significant relationship between homozygous mutation in the Vaspin gene and the age parameter ( $p=0.032$, OR:1.065, CI:1.005-1.128). The presence of homozygous mutation in the Vaspin gene risk of developing diabetes increases with age factor. However, there was no significant difference between Vaspin gene and genders in our study. On the other hand, Byung Son Youn et al. reported that the Vaspin serum level showed differences according to gender. It was observed that Vaspin serum levels in women increased approximately 2.5 -fold compared to men [22].

In the literature, the results of studies examining the relationship between diabetic obese and Chemerin gene polymorphism are inadequate. Therefore, we have examined Chemerin gene polymorphism in study groups. Chemerin secreted from white adipose tissue is a signal 
molecule with a variety of paracrine and autocrine effects and a new adipokine that regulated adipogenesis, metabolic homeostasis, glucose metabolism, inflammation, and many physiological processes in the cell. Weigert et al. showed that Chemerin serum level was similar in T2DM and obese individuals but was significantly increased in both cohorts compared to healthy individuals [24]. In the present study, we found no significant association between Chemerin gene polymorphism and study groups ( $\mathrm{p}>0.05$ ). In addition, the presence of homozygous mutation in Chemerin gene was not found to be statistically significant when examined in terms of somatic and biochemical parameters (such as age, BMI, LDL and AST).

The third step of our study is to examine the Visfatin gene polymorphism in study groups. The Visfatin are essentially produced by macrophages and play a major role in regulation of glucose transport and triacylglycerol (TAG) synthesis and was thus originally proposed to be insulin mimetic. In addition, Visfatin is recognized as a new proinflammatory adipocytokine and presumed to play an important role in inflammatory process of T2DM [25]. Sreedharan et. al. reported that the Visfatin serum levels were significantly higher in diabetic patients compared with nondiabetic group $(11.4 \pm 5.9 \rightarrow 9.8 \pm 4.3 \mathrm{ng} / \mathrm{mL}, p=.008)$. Moreover, within the non-diabetic group, the Visfatin serum levels were significantly higher in obese individual compared with non-obese individual $(10.4 \pm 4.7 \rightarrow 9.0 \pm$ $3.8 \mathrm{ng} / \mathrm{mL}, \mathrm{p}=.048)$ and the significance was maintained in terms of age and sex (OR:1.086; CI:1.003-1.176; p=.042) [26].

In our study, a statistically significant difference could not be found between diabetic obese and non-diabetic obese patients in regards of Visfatin gene polymorphism. However, in our study, we can say that the development of homozygous mutation in the Visfatin gene is statistically significant in terms of age parameter and the risk of diabetes may be higher in obese cases as the age gets older $(p<0.042)$. In our study, statistically significant results were not obtained in terms of biochemical parameters in the presence of homozygous mutation in the Visfatin gene.

Consequently, the statistically significant results were found in terms of Vaspin gene polymorphism in diabetic obese and non-diabetic obese patient groups. Accordingly, the combined effect of increasing age in obese individuals and the presence of homozygous mutations in the Vaspin gene may be a contributory risk of development of diabetes in obese individuals. Our other two genes, Chemerin and
Visfatin gene polymorphism, were not statistically significant difference between the groups resulting from low number of patients. The main problem of our study is that the genes and biochemical values are not statistically significant due to small number of patients. As a result, in order to understand the relationship between the development of T2DM in obese patients, Chemerin rs17173608, Vaspin rs2236242 and Visfatin rs2110385 polymorphisms should be developed in larger groups and with broader clinical data. We think that it will contribute to the literature as it constitutes the first data analyzed in terms of diabetes development among obese patients in Turkish society.

\section{REFERENCES}

1. "Obesity and Overweight." n.d. Accessed February 17, 2021. https://www.who.int/news-room/fact-sheets/detail/obesityand-overweight.

2. Türkiye'de Obezitenin Görülme Sıklı̆̆ı. n.d. Accessed February 17, 2021. https://hsgm.saglik.gov.tr/tr/obezite/ turkiyede-obezitenin-gorulme-sikligi.html.

3. Malik VS, Willett WC, and Hu FB. Global obesity: trends, risk factors and policy implications. Nature Reviews Endocrinology 2013.

4. Bruce R, Godsland IC, Walton C, Crook D, Wynn W. Associations between insulin sensitivity, and free fatty acid and triglyceride metabolism independent of uncomplicated obesity. Metabolism 1994; 43(10):1275-81.

5. Petersen KF and Shulman GI. Pathogenesis of skeletal muscle insulin resistance in type 2 diabetes mellitus. American Journal of Cardiology 2002; 90 (5 Suppl.): 11-18.

6. Lago F, Dieguez C, Gómez-Reino $\mathrm{J}$ and Gualillo $\mathrm{O}$. Adipokines as emerging mediators of immune response and inflammation. Nature Clinical Practice Rheumatology 2007

7. Zorena K, Duda OJ, Ślęzak D, Robakowska M and Mrugacz M. Adipokines and obesity. potential link to metabolic disorders and chronic complications. International Journal of Molecular Sciences 2020; 21 (10): 3570.

8. Pang SS and Le Y. Role of resistin in inflammation and inflammation-related diseases. Cell Mol Immunol 2006;3:29-34.

9. Yu Z, Han S, Cao X, Zhu C, Wang X, and Guo X. Genetic polymorphisms in adipokine genes and the risk of obesity: a systematic review and meta-analysis. Obesity 2012; 20 (2): 396-406.

10. Steppan CM and Lazar MA. 2004. The current biology of resistin. Journal of Internal Medicine 2004; 255 (4):439-47.

11. Pihlajamäki J, Ylinen $M$, Karhapää P, Vauhkonen I and Laakso M. The effect of the -308 a allele of the tnf $-\alpha$ gene on insulin action is dependent on obesity. Obesity Research 2003; 11(7):912-17.

12. Dimova $\mathrm{R}$ and Tankova $\mathrm{T}$. The role of vaspin in the development of metabolic and glucose tolerance disorders 
and atherosclerosis. BioMed Research International. Hindawi Limited 2015.

13. Antje K, Kratzsch J and Kiess W. Adipocytokines: leptin the classical, resistin - the controversical, adiponectin - the promising, and more to come. Best Practice and Research: Clinical Endocrinology and Metabolism. Baillière Tindall 2005.

14. Colhoun HM, McKeigue MP and Smith GD. Problems of reporting genetic associations with complex outcomes. Lancet. Elsevier Limited 2003.

15. Pearson TA and Manolio TA. How to interpret a genomewide association study. JAMA - Journal of the American Medical Association 2008; 299 (11): 1335-44.

16. Miller S. A simple salting-out proceddure tissue for extracting dna from human nucleated cells. N Ucleic Acids Research. 1988; 16: 221.

17. Hasanvand Z, Sadeghi A, Rezvanfar RM, Goodarzi MT, Rahmannezhad G and Mashayekhi FJ. Association between chemerin rs17173608 and rs4721 gene polymorphisms and gestational diabetes mellitus in iranian pregnant women. Gene 2018; 649 (April): 87-92.

18. Alnory A, Hoda Gad, Hegazy G and Shaker O. The association of vaspin rs2236242 and leptin rs7799039 polymorphism with metabolic syndrome in egyptian women. Turkish Journal Of Medical Sciences 2016; 46 (5): 1335-40.

19. Mirzaei K, Hossein-nezhad A, Hosseinzadeh-Attar M, Jafari $\mathrm{N}$, Najmafshar A and Larijani B. Variation in the visfatin gene may alter the required dosage of oral antidiabetic agents in type 2 diabetic patients. Journal of Diabetes and Lipid Disorders 2009; Vol.8..

20. Dunmore S and Brown JEP. The role of adipokines in betacell failure of type 2 diabetes. pituitary regulation of betacell function view project the effects of silibinin on glucose homeostasis and production of reactive oxygen species in c2c12 myoblasts view project the role of adipokines in b-cell failure of type 2 diabetes. Article in Journal of Endocrinology 2012.

21. Nora K, Berndt J, Kralisch S, Kovacs P, Fasshauer M, Schön MR, Stumvoll M and Blüher M. 2006. Vaspin gene expression in human adipose tissue: association with obesity and type 2 diabetes. Biochemical and Biophysical Research Communications 2006;339(1): 430-36.

22. Hida K, Wada J, Eguchi J, Zhang H, Baba M, Seida A, Hashimoto I, et al. Visceral adipose tissue-derived serine protease inhibitor: a unique insulin-sensitizing adipocytokine in obesity. Proceedings of the National Academy of Sciences of the United States of America 2005;102(30):10610-15.

23. Feng R, Li Y, Wang C, Luo C, Liu L, Chuo F, Li Q, and Sun C. Higher vaspin levels in subjects with obesity and type 2 diabetes mellitus: a meta-analysis. Diabetes Research and Clinical Practice 2014; 106(1):88-94.

24. Weigert J, Neumeier M, Wanninger J, Filarsky M, Bauer $\mathrm{S}$, Wiest R, Farkas S, et al. Systemic chemerin is related to inflammation rather than obesity in type 2 diabetes. Clinical Endocrinology 2010; 72 (3): 342-48.

25. Hetta HF, Ghada AM Marwa AG and Hala ME. Visfatin serum levels in obese type 2 diabetic patients: relation to proinflammatory cytokines and insulin resistance type 1 Diabetes Mellitus view project optimization of the effectiveness and cytocompatibility of Nigella Sativa as a cotreatment for reducing Methotrexate-related adverse effects view project. 2018.

26. Sandeep S, Velmurugan K, Deepa R, and Mohan V. Serum Visfatin in Relation to Visceral Fat, Obesity, and Type 2 Diabetes Mellitus in Asian Indians. Metabolism: Clinical and Experimental 2007; 56 (4):565-70. 